Buletin Ilmiah Math. Stat. dan Terapannya (Bimaster)

Volume 08, No. 4 (2019), hal 989 - 992.

\title{
KLASIFIKASI INDEKS PENCEMARAN KUALITAS AIR DI KOTA PONTIANAK
}

\author{
Ernita Saputri, Naomi Nessyana Debataraja, Setyo Wira Rizki
}

\begin{abstract}
INTISARI
Air merupakan bagian terpenting yang dibutuhkan dalam kehidupan, salah satunya untuk keperluan rumah tangga. Kegiatan manusia untuk keperluan rumah tangga yang semakin meningkat akan menimbulkan dampak pencemaran lingkungan khususnya pada pencemaran air. Data yang digunakan dalam penelitian ini adalah data primer yang terdiri dari 42 sampel air dari lokasi berbeda. Indikator fisik yang digunakan pada penelitian ini adalah kekeruhan, warna, dan Total Dissolved Solid (TDS). Berdasarkan indeks pencemaran, diperoleh tiga kriteria tingkat pencemaran air yaitu memenuhi baku mutu, tercemar ringan dan tercemar sedang. Hasil klasifikasi dengan menggunakan metode indeks pencemaran diperoleh total data yang memenuhi baku mutu sebanyak 8 titik lokasi,tercemar ringan sebanyak 24 titik lokasi tercemar ringan dan tercemar ringan sebanyak 10 titik lokasi.
\end{abstract}

Kata Kunci: pencemaran air, indeks pencemaran, indikator fisik

\section{PENDAHULUAN}

Air adalah sumber daya alam yang sangat dibutuhkan dalam kehidupan sehari-hari untuk memenuhi kebutuhan hidup manusia yang mana salah satunya untuk keperluan rumah tangga. Kegiatan manusia untuk keperluan rumah tangga yang semakin meningkat akan menimbulkan dampak pencemaran lingkungan khususnya pencemaran air. Pertumbuhan penduduk yang terus bertambah pastinya berbanding lurus dengan kebutuhan hidup manusia. Hal ini menjadi salah satu faktor pendukung dimana masalah utama yang dihadapi terkait dengan sumber daya air ialah kebutuhan pokok manusia yang terus meningkat tidak mampu terpenuhi oleh kuantitas air bersih yang tersedia dan menyebabkan terjadinya penurunan kualitas air dari tahun ke tahun. Apabila kondisi seperti ini terus berlangsung maka yang terjadi dimasa akan datang ialah munculnya gangguan, kerusakan dan bahaya bagi mahluk hidup yang bergantung pada sumber daya air.

Berdasarkan Peraturan Menteri Kesehatan Republik Indonesia Nomor 32 Tahun 2017 bahwa standar baku mutu kesehatan lingkungan dan persyaratan kesehatan air untuk keperluan higiene sanitasi. Air untuk keperluan higiene sanitasi tersebut digunakan untuk pemeliharaan kebersihan perorangan seperti mandi dan sikat gigi, serta untuk keperluan cuci bahan pangan, peralatan makan, dan pakaian. Selain itu air untuk keperluan higiene sanitasi dapat digunakan sebagai bahan baku air minum [1].

Langkah-langkah penelitian yaitu menentukan indeks pencemaran serta mementukan kriteria indeks pencemaran. Tujuan dari penelitian ini adalah menentukan indeks pencemaran (IP) dari parameter fisik dan mengklasifikasikan indeks pencemaran kualitas air di Kota Pontianak. Parameter fisik yang digunakan terdiri dari kekeruhan, warna dan total dissolved solid (TDS).

\section{METODE PENELITIAN}

Penelitian ini menggunakan data pada 42 sampel air dari lokasi yang berbeda-beda. Sampel diambil menggunakan metode stratified random sampling dimana populasi dikelompokkan menjadi sub-sub populasi dengan memperhatikan strata didalam populasi. Kemudian dari masing-masing sub populasi diambil titik-titik lokasi yang menjadi sampel [2]. Terpilihlah 42 titik lokasi yang digunakan sebagai sampel dengan menggunakan metode ini.

Indeks pencemaran digunakan untuk menentukan tingkat pencemaran yang relatif terhadap parameter kualitas air yang diizinkan. Pengelolaan kualitas air atas dasar Indeks Pencemaran (IP) dapat memberi masukan pada pengambilan keputusan agar dapat menilai kualitas badan air untuk 
suatu peruntukan serta melalukan tindakan untuk memperbaiki kualitas jika terjadi penurunan kualitas akibat adanya senyawa pencemaran. Indeks pencemaran (IP) ditentukan untuk suatu peruntukan, kemudian dapat dikembangkan untuk beberapa peruntukan bagi seluruh bagian badan air atau sebagian dari suatu sungai [3].

Jika $C_{x y}$ menyatakan nilai hasil penelitian pada variabel ke- $x$ lokasi ke- $y$ dan $L_{x y}$ menyatakan nilai baku mutu pada variabel ke- $x$ lokasi ke- $y$. Indeks pencemaran pada lokasi ke- $y$ yang merupakan fungsi dari $C_{x y} / L_{x y}$ adalah $I P_{y}[3]$.

$$
I P_{y}=\sqrt{\frac{K^{2}+N^{2}}{2}}
$$

Keterangan:

$$
\begin{aligned}
& I P_{y}=\text { indeks pencemaran air lokasi ke- } y \\
& K=\text { nilai rata-rata dari } C_{x y} / L_{x y} \\
& N=\text { nilai maksimum dari } C_{x y} / L_{x y}
\end{aligned}
$$

Metode ini dapat langsung menghubungkan tingkat ketercemaran dengan dapat atau tidaknya sungai dipakai untuk penggunaan tertentu dan dengan nilai parameter-parameter tertentu. Tabel 1 merupakan tabel kriteria indeks pencemaran.

Tabel 1 Kriteria Indeks Pencemaran

\begin{tabular}{ll}
\hline \multicolumn{1}{c}{ Kelas Indeks Pencemaran } & \multicolumn{1}{c}{ Keterangan } \\
\hline $0 \leq I P \leq 1,0$ & Memenuhi baku mutu \\
$1,0<I P \leq 5,0$ & Tercemar ringan \\
$5,0<I P \leq 10$ & Tercemar sedang \\
$I P>10$ & Tercemar berat \\
\hline Sumber: Keputusan Menteri Negara Lingkungan Hidup Nomor 115 Tahun 2003
\end{tabular}

Harga $I P_{y}$ ini dapat ditentukan dengan cara:

1. Perhitungan nilai $C_{x y} / L_{x y}$ untuk tiap variabel pada setiap lokasi pengambilan sampel.

2. Apabila nilai $C_{x y} / L_{x y}<1$ maka digunakan nilai $C_{x y} / L_{x y}$ sebagai hasil pengukuran dan apabila nilai $C_{x y} / L_{x y}>1$ maka digunakan nilai $C_{x y} / L_{x y}$ baru sebagai hasil pengukuran. Rumus yang digunakan untuk memperoleh nilai $C_{x y} / L_{x y}$ baru $=1,0+P \cdot \log \left(C_{x y} / L_{x y}\right)$, dimana $P$ adalah konstanta dan nilainya ditentukan dengan bebas (biasanya digunakan 5).

3. Penentuan nilai rata-rata dan nilai maksimum dari keseluruhan $C_{x y} / L_{x y}$.

4. Penentuan nilai $I P_{y}$.

\section{HASIL DAN PEMBAHASAN}

Baku mutu dan hasil laboratorium parameter fisik air untuk keperluan higiene sanitasi dapat dilihat pada tabel dan diagram berikut.

Tabel 2 Standar Baku Mutu Parameter Fisik

\begin{tabular}{cccc}
\hline No & Parameter Wajib & $\begin{array}{c}\text { Standar Baku Mutu } \\
\text { (Kadar Maksimum) }\end{array}$ & Satuan \\
\hline 1 & Kekeruhan & 25 & Nephelometric Turbidity Unit (NTU) \\
2 & Warna & 50 & True Color Unit (TCU) \\
3 & Zat Padat Terlarut & 1000 & $\mathrm{Mg} / 1$ \\
& (Total Dissolved Solid) & &
\end{tabular}

Standar baku mutu air yang digunakan adalah standar baku mutu kesehatan lingkungan dan persyaratan kesehatan air untuk keperluan higiene sanitasi, yang diatur dalam Peraturan Menteri 
Kesehatan Republik Indonesia Nomor 32 Tahun 2017 [1]. Hasil yang diperoleh dari laboratoriumnya dapat dilihat pada Tabel 3.

Tabel 3 Hasil Kategori Pencemaran Air

\begin{tabular}{ccc}
\hline \multirow{2}{*}{ Parameter Fisik } & \multicolumn{2}{c}{ Jumlah Sampel } \\
\cline { 2 - 3 } & Tercemar & Tidak Tercemar \\
\hline Kekeruhan & 10 & 32 \\
Warna & 35 & 7 \\
Total Dissolved Solid & 0 & 42 \\
\hline
\end{tabular}

Parameter fisik untuk kekeruhan yang tercemar sebanyak 10 titik lokasi sampel dan warna yang tercemar sebanyak 35 titik lokasi sampel. Sehingga dilakukan penelitian mengenai penentuan kualitas air menggunakan indeks pencemaran. Tabel 3 menyajikan hasil perhitungan nilai indeks pencemaran untuk parameter fisik.

Tabel 4 Nilai Indeks Pencemaran Parameter Fisik Sampel Pertama

\begin{tabular}{ccccc}
\hline Variabel & $C_{x y}$ & $L_{x y}$ & $\left(C_{x y} / L_{x y}\right)$ & $\left(C_{x y} / L_{x y}\right)$ baru \\
\hline Kekeruhan & 55,1 & 25 & 2,204 & 2,71606 \\
Warna & 785 & 50 & 15,7 & 6,9795 \\
TDS & 17,2 & 1000 & 0,0172 & 0,0172 \\
\hline$K^{2}$ & & & & 10,4819593 \\
$N^{2}$ & & & & 48,7134 \\
$I P_{y}$ & & & 5,440375 \\
\hline
\end{tabular}

Pada Tabel 4 didapat hasil indeks pencemaran untuk sampel pertama sebesat 5,440375. Menurut tabel kriteria indeks pencemaran sampel pertama termasuk dalam kategori tercemar sedang. Hasil perhitungan seluruh sampel indikator fisik dapat dilihat pada Tabel 5.

Tabel 5 Nilai Indeks Pencemaran Parameter Fisik

\begin{tabular}{cccccc}
\hline Sampel & $I P_{y}$ & Kriteria Indeks Pencemaran & Sampel & $I P_{y}$ & Kriteria Indeks Pencemaran \\
\hline 1 & 5,440375 & Tercemar sedang & 22 & 4,463715 & Tercemar ringan \\
2 & 5,41935 & Tercemar sedang & 23 & 4,255671 & Tercemar ringan \\
3 & 5,825755 & Tercemar sedang & 24 & 4,961251 & Tercemar ringan \\
4 & 5,412943 & Tercemar sedang & 25 & 4,466458 & Tercemar ringan \\
5 & 5,509195 & Tercemar sedang & 26 & 0,788546 & Memenuhi Baku Mutu \\
6 & 4,484888 & Tercemar ringan & 27 & 4,999726 & Tercemar ringan \\
7 & 5,407533 & Tercemar sedang & 28 & 2,129691 & Tercemar ringan \\
8 & 5,630898 & Tercemar sedang & 29 & 4,917998 & Tercemar ringan \\
9 & 4,839126 & Tercemar ringan & 30 & 5,1099 & Tercemar sedang \\
10 & 0,683873 & Memenuhi Baku Mutu & 31 & 5,228082 & Tercemar sedang \\
11 & 2,763823 & Tercemar ringan & 32 & 2,800144 & Tercemar ringan \\
12 & 2,82216 & Tercemar ringan & 33 & 0,516578 & Memenuhi Baku Mutu \\
13 & 0,738324 & Memenuhi Baku Mutu & 34 & 1,772955 & Tercemar ringan \\
14 & 5,405725 & Tercemar sedang & 35 & 2,788535 & Tercemar ringan \\
15 & 1,410339 & Tercemar ringan & 36 & 1,84262 & Tercemar ringan \\
16 & 0,946004 & Memenuhi Baku Mutu & 37 & 1,709521 & Tercemar ringan \\
17 & 1,441701 & Tercemar ringan & 38 & 3,230933 & Tercemar ringan \\
18 & 0,528815 & Memenuhi Baku Mutu & 39 & 3,677802 & Tercemar ringan \\
19 & 1,872464 & Tercemar ringan & 40 & 2,872906 & Tercemar ringan \\
20 & 0,489871 & Memenuhi Baku Mutu & 41 & 2,464229 & Tercemar ringan \\
21 & 0,381449 & Memenuhi Baku Mutu & 42 & 1,686999 & Tercemar ringan \\
\hline
\end{tabular}


Berdasarkan hasil perhitungan diperoleh kriteria indeks pencemaran pada parameter fisik yaitu memenuhi baku mutu, tercemar ringan, dan tercemar sedang. Kelas indeks pencemaran yang termasuk kategori memenuhi baku mutu sebanyak 8 titik lokasi sampel. Kelas indeks pencemaran yang termasuk tercemar ringan sebanyak 24 titik lokasi sampel. Kelas indeks pencemaran yang termasuk tercemar sedang sebanyak 10 titik lokasi sampel. Gambar 1 menyajikan peta hasil klasifikasi dengan menggunakan indeks pencemaran.

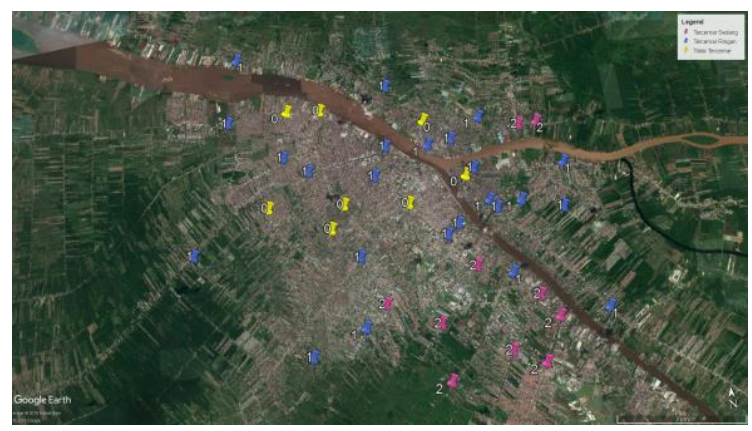

Gambar 1. Peta Titik Lokasi Sampel Parameter Fisik

\section{KESIMPULAN}

Berdasarkan hasil perhitungan menggunakan indeks pencemaran dapat disimpulkan bahwa hasil indeks pencemaran untuk parameter fisik terdiri dari tiga kriteria indeks pencemaran yaitu, 8 titik lokasi sampel memenuhi baku mutu, 24 titik lokasi sampel tercemar ringan, dan 10 titik lokasi sampel tercemar sedang.

\section{UCAPAN TERIMA KASIH}

Ucapan terima kasih disampaikan kepada Kementerian Riset, Teknologi, dan Pendidikan Tinggi atas dukungan dana bagi penelitian ini yang diberikan kepada Dadan Kusnandar, Naomi Nessyana Debataraja, dan Rossi Widya Nusantara. Makalah ini merupakan bagian dari hasil penelitian tersebut. Analisis diskriminan terhadap data dalam penelitian ini dipublikasikan dalam jurnal The $4^{\text {th }}$ IICMA 2019 Proceeding, AIP Publication.

\section{DAFTAR PUSTAKA}

[1]. Republik Indonesia. Peraturan Menteri Kesehatan Republik Indonesia Nomor 32 Tahun 2017 Tentang Standar Baku Mutu Kesehatan Lingkungan dan Persyaratan Kesehatan Air Untuk Keperluan Higiene Sanitasi, Kolam Renang, Solus per Aqua dan Pemandian Umum. Sekretariat Negara. Jakarta; 2017.

[2]. Debataraja, N. N., Kusnandar, D., dan Nusantara, R. W. Identifikasi Lokasi Sebaran Pencemaran Air di Kawasan Permukiman Kota Pontianak. Jurnal Matematika, Statistika, dan Komputasi. 2018; 15(1); 37-41.

[3]. Republik Indonesia. Peraturan Menteri Lingkungan Hidup Nomor 115 Tahun 2003 Tentang Pedoman Penentuan Status Mutu Air. Jakarta; 2003.

[4]. Andara, D. R., Haeruddin, dan Suryoanto, A. Kandungan Total Padatan Tersuspensi, Biochemical Oxygen Demand dan Chemical Oxygen Demand serta Indeks Pencemaran Sungai Klampisan di Kawasan Industri Candi, Semarang. Diponegoro Journal of Maquares. 3(3): 177-187; 2014.

ERNITA SAPUTRI

NAOMI NESSYANA DEBATARAJA

SETYO WIRA RIZKI
: Jurusan Matematika FMIPA UNTAN, Pontianak ernitasaputri48@gmail.com

Jurusan Matematika FMIPA UNTAN, Pontianak naominessyana@math.untan.ac.id

: Jurusan Matematika FMIPA UNTAN, Pontianak setyo.wirarizki@math.untan.ac.id 
